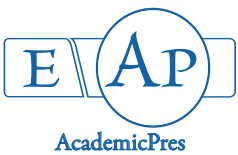

Eze PM et al. (2021)

Notulae Scientia Biologicae

Volume 13, Issue 3, Article number 11020

DOI: $10.15835 / \mathrm{nsb} 13311020$

Research Article

\title{
Secondary metabolites of a marine-derived Penicillium ochrochloron
}

\author{
Peter M. EZE ${ }^{1,2 *}$, Ying $\mathrm{GAO}^{2}$, Yang $\mathrm{LIU}^{3}$, Lasse van GEELEN ${ }^{2}$, \\ Chika P. EJIKEUGWU ${ }^{4}$, Charles O. ESIMONE ${ }^{5}$, Festus B.C. OKOYE ${ }^{6}$, \\ Peter PROKSCH${ }^{2}$, Rainer KALSCHEUER ${ }^{2}$
}

\author{
${ }^{1}$ Nnamdi Azikiwe University, Faculty of Health Sciences and Technology, Department of Environmental Health Sciences, Awka, \\ Nigeria; pm.eze@unizik.edu.ng (*corresponding author) \\ ${ }^{2}$ Heinrich Heine University, Institute of Pharmaceutical Biology and Biotechnology, Düsseldorf, Germany; gaoying446@163.com; \\ lasse.geelen@hhu.de;proksch@hhu.de; rainer.kalscheuer@hhu.de \\ ${ }_{3}^{3}$ ustus Liebig University, Institute for Insect Biotechnology, Gießen, Germany; liu.yang@agrar.uni-giessen.de \\ ${ }^{4}$ Ebonyi State University, Department of Applied Microbiology, Abakiliki, Nigeria; chika.ejikeugwu@ebsu.edu.ng \\ ${ }^{5}$ Nnamdi Azikiwe University, Faculty of Pharmaceutical Sciences, Department of Pharmaceutical Microbiology and Biotechnology, \\ Awka,Nigeria; co.esimone@unizik.edu.ng \\ ${ }^{6}$ Nnamdi Azikiwe University, Faculty of Pharmaceutical Sciences, Department of Pharmaceutical and Medicinal Chemistry, Awka, \\ Nigeria; fb.okoye@unizik.edu.ng
}

\begin{abstract}
Extremophilic fungi have received considerable attention recently as new promising sources of biologically active compounds with potential pharmaceutical applications. This study investigated the secondary metabolites of a marine-derived Penicillium ochrochloron isolated from underwater sea sand collected from the North Sea in St. Peter-Ording, Germany. Standard techniques were used for fungal isolation, taxonomic identification, fermentation, extraction, and isolation of fungal secondary metabolites. Chromatographic separation and spectroscopic analyses of the fungal secondary metabolites yielded eight compounds: talumarin A (1), aspergillumarin A (2), andrastin A (3), clavatol (4), 3-acetylphenol (5), methyl 2,5-dihydro-4-hydroxy-5-oxo-3-phenyl-2-furanpropanoate (6), emodin (7) and 2-chloroemodin (8). After cocultivation with Bacillus subtilis, the fungus was induced to express (-)-striatisporolide A (9). Compound 1 was evaluated for antibacterial activity against Staphylococcus aureus, Acinetobacter baumannii, Mycobacterium smegmatis, and M. tuberculosis, as well as cytotoxicity against THP-1 cells. The compound, however, was not cytotoxic to THP-1 cells and had no antibacterial activity against the microorganisms tested. The compounds isolated from $P$. ochrochloron in this study are well-known compounds with a wide range of beneficial biological properties that can be explored for pharmaceutical, agricultural, or industrial applications. This study highlights the bioprospecting potential of marine fungi and confirms co-cultivation as a useful strategy for the discovery of new natural products.
\end{abstract}

Keywords: drug discovery; marine fungus; natural products; Penicillium ochrochloron; secondary metabolites

Received: 08 Jul 2021. Received in revised form: 25 Aug 2021. Accepted: 02 Sep 2021. Published online: 09 Sep 2021.

From Volume 13, Issue 1, 2021, Notulae Scientia Biologicae journal uses article numbers in place of the traditional method of continuous pagination through the volume. The journal will continue to appear quarterly, as before, with four annual numbers. 


\section{Introduction}

The frequent re-isolation of known metabolites from fungi has turned the interest of natural products chemists to hitherto less investigated ecological niches such as arctic glaciers, deep-sea hydrothermal vents or hypersaline lakes (Wilson and Brimble, 2009; Liu et al., 2016). Fungi that live at elevated temperature, acidic or alkaline $\mathrm{pH}$, high pressure, high salt concentration and /or low nutrient concentrations are called extremophiles. These fungi have developed unique metabolic mechanisms to produce bioactive secondary metabolites as a response to environmental stress (Satyanarayana et al., 2005; Ma et al., 2010).

Marine fungi are distinct from their terrestrial and freshwater counterparts, both in their taxonomy, morphology and adaptation to an aquatic habitat. When compared to the thousands of fungal species known from terrestrial environments, only a few have been described for oceans and estuaries which represent the largest part of the earth's surface. Some of these fungi, however, may occur in both seawater and freshwater or terrestrial habitats (Jones, 2000; Gomes et al., 2008).

These marine species represent a huge potential for new natural products and an increased number of new metabolites have become known over the past years, while much of the hidden potential still needs to be uncovered. Though bioactivities of secondary metabolites from marine fungi reveal interesting levels for several clinically relevant targets, they are not well represented in the pipelines of drugs and none of them currently is on the market. However, in recent years, an increasing number of new natural products have been characterized from marine fungi and there is no doubt that they produce a large number of interesting secondary metabolites, which often show pharmaceutically relevant bioactivities and may be candidates for the development of new drugs (Imhoff et al., 2011; Imhoff, 2016).

The prospects of extremophilic fungi as new promising sources for biologically active compounds with potential pharmaceutical applications inspired this current study.

\section{Materials and Methods}

\section{Fungal isolation and identification}

Sea sand collected from underwater at the North Sea in St. Peter-Ording, Germany was inoculated in malt extract agar plates and incubated at $22^{\circ} \mathrm{C}$ for 3-5 days. The observed fungal growths were subcultured onto freshly prepared agar plates to obtain pure cultures. One of the fungi was identified as Penicillium ochrochloron according to the molecular identification protocol of DNA amplification and sequencing of the internal transcribed spacer (ITS) region previously described (Kjer et al., 2010). The DNA sequence data was deposited in the NCBI database (GenBank) with accession number MN475865.

\section{Fermentation and co-cultivation}

Solid state fermentation of $P$. ochrochloron was carried out by cultivating the fungus in $1 \mathrm{~L}$ Erlenmeyer flask containing sterile solid rice medium $\left(100 \mathrm{~g}\right.$ of rice $+110 \mathrm{~mL}$ of distilled water, autoclaved at $121^{\circ} \mathrm{C}$ at 15 psi for $20 \mathrm{~min}$ ) under static conditions at $22^{\circ} \mathrm{C}$ for 14 days (Eze et al., 2018). Also, co-cultivation experiments were performed by growing the fungus in I L Erlenmeyer flasks containing rice medium to which broth solution of freshly grown Bacillus subtilis was added (Moussa et al., 2020).

\section{Extraction and isolation of metabolites}

After fermentation, the fungal secondary metabolites were extracted with ethyl acetate (EtOAc) and then concentrated under reduced pressure. UV-guided column chromatographic separation of the crude EtOAc axenic extract using silica gel and Sephadex LH-20 as stationary phases followed by purification with semi-preparative reversed-phase HPLC yielded compounds (1-8). Also, chromatographic separation of the coculture extract afforded compound 9. Initially, the crude axenic fungal extract was subjected to VLC with silica 
using gradient mixtures of $n$-hexane $(n-\mathrm{Hex})$ and EtOAc to yield 4 fractions PO1 - PO4. Fraction PO2 [ $n$ Hex:EtOAc (80:20) was divided into two parts by dissolving in methanol $(\mathrm{MeOH})$ to yield $\mathrm{MeOH}$-soluble and $\mathrm{MeOH}$-insoluble parts. The $\mathrm{MeOH}$-soluble part was subjected to a Sephadex LH-20 column using 100\% $\mathrm{MeOH}$ as eluent to obtain 7 sub-fractions (PO21 to PO27). Sub-fraction PO23 was purified by semipreparative HPLC using $\mathrm{MeOH}: \mathrm{H}_{2} \mathrm{O}$ (30:70 to 70:30) to give compound 2 (code: $\mathrm{PO} 232 ; 9.2 \mathrm{mg}$ ). Subfraction $\mathrm{PO} 24$ was purified by semi-preparative HPLC using MeOH-H $\mathrm{H}_{2} \mathrm{O}(10: 90$ to 55:45) to give compound 4 (code: PO241; $1.4 \mathrm{mg}$ ), compound 5 (code: PO242; $1.0 \mathrm{mg}$ ), compound 6 (code: PO243; $2.0 \mathrm{mg}$ ). Subfraction $\mathrm{PO} 27$ was purified by semi-preparative HPLC using $\mathrm{MeOH}-\mathrm{H}_{2} \mathrm{O}$ (65:35 to 95:5) to give compound 7 (code: PO271; $1.0 \mathrm{mg}$ ) and compound 8 (code: PO272; $2.1 \mathrm{mg}$ ). Fraction PO4 was subjected to Sephadex LH-20 column using $100 \% \mathrm{MeOH}$ as eluent to obtain 8 sub-fractions (PO41 to PO48). Sub-fractions PO43 and $\mathrm{PO} 42$ were then subjected to semi-preparative HPLC using $\mathrm{MeOH}-\mathrm{H}_{2} \mathrm{O}$ (70:30 to 90:10) to yield compound 1 (PO432; $6.2 \mathrm{mg}$ ) and compound 3 (codes: PO42211 and RP(MeOH)-70\%A-E; $13.3 \mathrm{mg}$ ) respectively. The crude extract $(1.5 \mathrm{~g})$ resulting from the co-cultivation experiment was subjected to VLC in silica gel with gradient mixtures of $n$-Hex and EtOAc. One of the fractions [ $n$-Hex:EtOAc (70:30); $110 \mathrm{mg}$ ] was subjected to Sephadex LH-20 column using 100\% MeOH to yield 14 sub-fractions (70\%C-Hex-Seph-1 to $70 \% \mathrm{C}-\mathrm{Hex}-\mathrm{Seph}-14$ ). Semi-preparative HPLC of sub-fraction $70 \% \mathrm{C}-\mathrm{Hex}-\mathrm{Seph}-4$ using $\mathrm{MeOH}-\mathrm{H}_{2} \mathrm{O}$ (70:30 to 95:5) yielded compound 9 (code: 70\%C-Hex-Seph-4-D; $21 \mathrm{mg}$ ).

\section{General experimental procedures}

NMR measurements of the isolated compounds were carried out either in deuterated $\mathrm{MeOH}$, dimethyl sulfoxide (DMSO) or chloroform $\left(\mathrm{CHCl}_{3}\right)$ using a Bruker Avance DMX 300 and 600 spectrometers (Bruker BioSpin, Germany). The NMR spectra were referenced relative to the residual solvent signals. For mass spectral analysis, ESI-MS and HR-ESIMS were measured with a UHR-QTOF maXis 4G mass spectrometer (Bruker Daltonik, Germany). Analytical HPLC analysis was carried out using a Dionex P580 system coupled to a P580A LPG pump and a photodiode array detector (UVD340s, Dionex Softron, Germany). The HPLC instrument consists of a separation column $(125 \times 4 \mathrm{~mm})$ prefilled with Eurosphere-10 C18 (Knauer, Germany) with $\mathrm{MeOH}$ and $\mathrm{H}_{2} \mathrm{O}$ mixtures as the gradient solvent system. Semi-preparative HPLC was performed using a Merck-Hitachi HPLC System comprising of a UV detector (L-7400), pump (L-7100), and a Eurosphere column $\left(100 \mathrm{C} 18,300 \times 8 \mathrm{~mm}\right.$, Knauer, Germany). Gradient $\mathrm{MeOH}-\mathrm{H}_{2} \mathrm{O}$ mixtures were used as the mobile phase at a flow rate of $5.0 \mathrm{~mL} / \mathrm{min}$. Vacuum liquid chromatography was carried out using silica gel 60 (230-400 mesh, Merck, Germany) and $\mathrm{C}_{18}$-reversed phase (RP) silica gel (230-400 mesh, Merck, Germany). Open column chromatography was carried out using Sephadex LH-20 (Sigma-Aldrich, Germany). Pre-coated TLC plates (silica gel 60 F254, 20×20 cm, $0.25 \mathrm{~mm}$ thick, Merck, Germany) were used to monitor fractions under UV detection (Camag UV cabinet, Germany) at 254 and $366 \mathrm{~nm}$. The optical rotation of compounds was measured in $\mathrm{MeOH}$ using a P-2000 polarimeter (Jasco, Germany). Distilled solvents were used for column chromatography and spectral-grade solvents were used for spectroscopic measurements.

\section{Antimicrobial assay}

The antibacterial activity of compound 1 was determined at concentrations of 100 to $0.049 \mu \mathrm{M}$ against Staphylococcus aureus (ATCC 29213) and Acinetobacter baumannii (BAA 1605) using the Clinical and Laboratory Standards Institute (CLSI) broth micro-dilution method in Müller Hinton broth (CLSI, 2012). Ciprofloxacin (100 to $0.049 \mu \mathrm{g} / \mathrm{mL}$ ) and DMSO (100\%, v/v) were used as positive and negative controls respectively. Also, the antimycobacterial activity of the compound against Mycobacterium smegmatis $\left(\mathrm{mc}^{2}\right.$ 155) and M. tuberculosis (H37Rv) was evaluated using the method described by Daletos et al. (2015). Cultures of the mycobacterial cells previously grown aerobically at $37^{\circ} \mathrm{C}, 5 \% \mathrm{CO}_{2}$ and $85 \%$ humidity in Middlebrook 7H9 media supplemented with $0.5 \%(\mathrm{v} / \mathrm{v})$ glycerol, $0.05 \%(\mathrm{v} / \mathrm{v})$ Tyloxapol, and $10 \%(\mathrm{v} / \mathrm{v})$ ADS enrichment ( $5 \%, \mathrm{w} / \mathrm{v}$, bovine serum albumin fraction $\mathrm{V} ; 2 \%, \mathrm{w} / \mathrm{v}$, glucose; $0.85 \%$, w/v, sodium chloride) were standardized (OD $600 \mathrm{~nm} \sim 0.08$ ) and then seeded in a 96-well round-bottom microtiter plate at $1 \times 10^{5}$ cells per well and 
incubated with test substances in a total volume of $100 \mu \mathrm{L}$ for 5 days. Rifampicin (100 to $0.049 \mu \mathrm{g} / \mathrm{mL})$ and DMSO $(100 \%, v / v)$ were used as positive and negative controls respectively. To determine the viability of the cells, $10 \mu \mathrm{L}$ of a $100 \mu \mathrm{g} / \mathrm{mL}$ resazurin solution (Sigma-Aldrich) was added into each well and the plates were incubated for ca. $8 \mathrm{~h}$. Then cells were fixed at room temperature for $30 \mathrm{~min}$ after addition of formalin $(5 \% \mathrm{v} / \mathrm{v}$, final concentration), and fluorescence was measured using a TECAN microplate reader (excitation $540 \mathrm{~nm}$, emission $590 \mathrm{~nm}$ ). Residual growth was calculated relative to the sterile medium ( $0 \%$ growth) and DMSOtreated (100\% growth) controls.

\section{Cytotoxicity assay}

Cytotoxicity study on compound 1 was conducted using the THP-1 cell line (human monocytic leukemia cell line) as previously described (Meier et al., 2019). The cells were cultured in RPMI 1640 medium containing $10 \%$ fetal bovine serum (FBS) at $37{ }^{\circ} \mathrm{C}$ in a humidified atmosphere of $5 \% \mathrm{CO}_{2}$ for 5 days. Afterwards, the cells were suspended and adjusted to a density of $1 \times 10^{6}$ cells $/ \mathrm{mL}$. Cells were then seeded into a 96-well flat-bottom plate in a total volume of $100 \mu \mathrm{L}$ containing 2-fold serial dilutions of the tested compound in a concentration ranging from 100 to $0.049 \mu \mathrm{M}$. Cycloheximide (100 to $0.049 \mu \mathrm{g} / \mathrm{mL}$ ) was used as positive control. After $48 \mathrm{~h}$ incubation at $37^{\circ} \mathrm{C}$ in a humidified atmosphere of $5 \% \mathrm{CO}_{2}, 10 \mu \mathrm{L}$ resazurin solution $(100 \mu \mathrm{g} / \mathrm{mL})$ was added to each well and incubated for a further $4 \mathrm{~h}$. Afterwards, fluorescence was quantified using a Tecan Infinite 200pro microplate reader (excitation $540 \mathrm{~nm}$, emission $590 \mathrm{~nm}$ ). Residual growth was calculated relative to non-inoculated ( $0 \%$ growth) and DMSO - treated (100\% growth) controls, respectively.

\section{Results}

Chromatographic separation and spectroscopic analyses of the fungal extract resulted in the isolation of eight compounds 1-8. Co-culture of $P$. ochrochloron with B. subtilis resulted in the expression of compound 9 previously undetected in extract of the fungal axenic culture. Structures of the isolated compounds are shown in Figures 1 and 2.

\section{Isolated compounds}

Talumarin A (1)

Compound 1 exhibited $[\alpha]_{D}^{20}=-49(c=0.8, \mathrm{MeOH})$, and UV $(\mathrm{MeOH}) \lambda_{\max } 206.7,247.2$, and 313.7 characteristic of dihydroisocoumarin nucleus. The molecular formula was deduced as $\mathrm{C}_{12} \mathrm{H}_{12} \mathrm{O}_{6}$ based on the prominent pseudomolecular ion peak at $\mathrm{m} / \mathrm{z} 253.0706[\mathrm{M}+\mathrm{H}]^{+}$in the HRESIMS spectrum. Results of the ${ }^{1} \mathrm{H}-\mathrm{NMR}$ and 2-D NMR $\left(600 \mathrm{MHz}, \mathrm{MeOH}-d_{4}\right)$ spectroscopic analyses are confirmed by a previous report (Küppers et al., 2017).

\section{Aspergillumarin A (2)}

$\mathrm{UV}(\mathrm{MeOH}) \lambda_{\max }$ of compound 2 were at $239.6,255.1$ and $308.8 \mathrm{~nm}$. The molecular formula was deduced as $\mathrm{C}_{14} \mathrm{H}_{16} \mathrm{O}_{4}$ on the basis of the $[\mathrm{M}+\mathrm{H}]^{+}$signal at $\mathrm{m} / \mathrm{z} 249.4$ (calculated as 248.4 ) in the ESIMS. Results of the ${ }^{1} \mathrm{H}-\mathrm{NMR}\left(300 \mathrm{MHz}, \mathrm{MeOH}-d_{4} ; 600 \mathrm{MHz}, \mathrm{CHCl}_{3}\right.$-d) spectroscopic analyses are confirmed by previous reports (Qi et al., 2013; Luo et al., 2019).

\section{Andrastin A (3)}

The molecular formula of compound 3 was deduced as $\mathrm{C}_{28} \mathrm{H}_{38} \mathrm{O}_{7}$ on the basis of the $[\mathrm{M}-\mathrm{H}]^{+}$signal at $\mathrm{m} / \mathrm{z} 485.4$ (calculated as 486.4) in the ESIMS. UV (MeOH) $\lambda_{\max }$ were at 201.4 and $262.1 \mathrm{~nm}$. Results of the ${ }^{1} \mathrm{H}-\mathrm{NMR}\left(300 \mathrm{MHz}, \mathrm{MeOH}-d_{4}\right)$ spectroscopic analyses are consistent with previous reports (Overy et al., 2005; O'Brien et al., 2006; Rojas-Aedo et al., 2018). 
<smiles>O=C(O)CC[C@H]1Cc2ccc(O)c(O)c2C(=O)O1</smiles>

1<smiles>CC(=O)c1cc(C)c(O)c(C)c1O</smiles>

4<smiles>Cc1cc(O)c2c(c1)C(=O)c1cc(O)cc(O)c1C2=O</smiles>

7<smiles>CC(=O)CCC[C@H]1Cc2cccc(O)c2C(=O)O1</smiles>

2<smiles>CC(=O)c1cccc(O)c1</smiles>

5

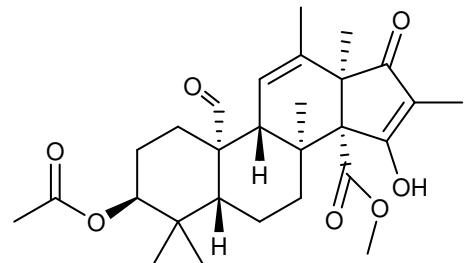

3<smiles>COC(=O)CCC1OC(=O)C(O)=C1c1ccccc1</smiles>

6<smiles>Cc1cc(O)c2c(c1)C(=O)c1cc(O)c(Cl)c(O)c1C2=O</smiles>

Figure 1. Compounds isolated from the fermentation extract of $P$. ochrochloron

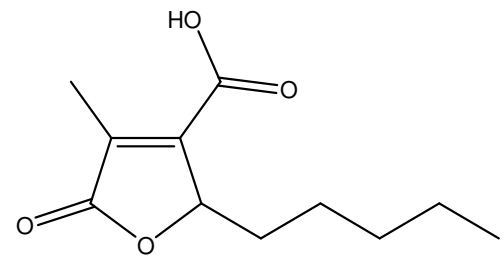

9

Figure 2. Compound isolated after co-cultivating P. ochrochloron with B. subtilis

\section{Bioassays}

At the concentrations analysed (100-0.049 $\mu \mathrm{M})$, compound 1 was not active against $S$. aureus, $A$. baumannii, M. smegmatis and M. tuberculosis, and did not show cytotoxicity to THP-1 cells.

Clavatol (4)

$\mathrm{UV}(\mathrm{MeOH}) \lambda_{\max }$ of compound 4 were at $216.3,286.2$ and $328.4 \mathrm{~nm}$. The molecular formula was deduced as $\mathrm{C}_{10} \mathrm{H}_{12} \mathrm{O}_{3}$ on the basis of the $[\mathrm{M}+\mathrm{H}]^{+}$signal at $181.3 \mathrm{~m} / \mathrm{z}$ (calculated as 180$)$ in the ESIMS. Results of the ${ }^{1} \mathrm{H}-\mathrm{NMR}\left(600 \mathrm{MHz}, \mathrm{MeOH}-d_{4}\right)$ spectroscopic analyses are confirmed by previous reports (da Silva and Rodrigues-Fo, 2010; da Silva et al., 2013). 
3-Acetylphenol, also known as 3-hydroxyacetophenone (5)

$\mathrm{UV}(\mathrm{MeOH}) \lambda_{\max }$ of compound 5 were at 216.9, 251.0, and $308.9 \mathrm{~nm}$. The molecular formula was deduced as $\mathrm{C}_{8} \mathrm{H}_{8} \mathrm{O}_{2}$ on the basis of the $[\mathrm{M}-\mathrm{H}]^{+}$signal at $\mathrm{m} / \mathrm{z} 137.1$ (calculated as 136) in the ESIMS. Results of the ${ }^{1} \mathrm{H}-\mathrm{NMR}\left(300 \mathrm{MHz}, \mathrm{MeOH}-d_{4}\right)$ spectroscopic analyses are confirmed by a previous report (Reio, 1959).

Methyl 2,5-dihydro-4-hydroxy-5-oxo-3-phenyl-2-furanpropanoate (6)

The molecular formula of compound 6 was deduced as $\mathrm{C}_{14} \mathrm{H}_{14} \mathrm{O}_{5}$ on the basis of the $[\mathrm{M}+\mathrm{H}]^{+}$and $[\mathrm{M}+\mathrm{Na}]$ signals at $\mathrm{m} / \mathrm{z} 263.3$ and 285.3 respectively (calculated as 262.3 ) in the ESIMS. Results of the ${ }^{1} \mathrm{H}$ $\mathrm{NMR}\left(300 \mathrm{MHz}, \mathrm{MeOH}-d_{4}\right)$ spectroscopic analyses are consistent with the report of Ancheeva et al. (2017).

$\underline{\operatorname{Emodin}(7)}$

The molecular formula of compound 7 was deduced as $\mathrm{C}_{15} \mathrm{H}_{10} \mathrm{O}_{5}$ on the basis of the $[\mathrm{M}-\mathrm{H}]^{+}$signal at $\mathrm{m} / \mathrm{z} 269.3$ (calculated as 270.3) in the ESIMS. UV (MeOH) $\lambda_{\max }$ were at $220.8,266.5$, and $288.0 \mathrm{~nm}$. Results of the ${ }^{1} \mathrm{H}-\mathrm{NMR}\left(300 \mathrm{MHz}\right.$, DMSO- $d_{6}$ ) spectroscopic analyses are confirmed by previous reports (Frisvad, 1989; Wang et al., 2014).

2-chloroemodin, also known as 7-chloroemodin (8)

$\mathrm{UV}(\mathrm{MeOH}) \lambda_{\max }$ of compound 8 were at $221.8,272.4$, and $433.9 \mathrm{~nm}$. The molecular formula was deduced as $\mathrm{C}_{15} \mathrm{H}_{9} \mathrm{ClO}_{5}$ on the basis of the $[\mathrm{M}+\mathrm{H}]^{+}$signal at $\mathrm{m} / \mathrm{z} 305.0213$ (calculated as 304.0133 ) in the HRESIMS. Results of the ${ }^{1} \mathrm{H}-\mathrm{NMR}\left(300 \mathrm{MHz}, \mathrm{DMSO}-d_{6}\right)$ spectroscopic analyses are confirmed by previous reports (Frisvad et al., 2009).

\section{(-)-Striatisporolide A (9)}

This compound was produced by $P$. ochrochloron after co-cultivation with B. subtilis. Compound 9 exhibited $[\alpha]_{D}^{20}=-25(c=0.20, \mathrm{MeOH})$, and UV $(\mathrm{MeOH}) \lambda_{\max }$ was at $229.5 \mathrm{~nm}$. The molecular formula was deduced as $\mathrm{C}_{11} \mathrm{H}_{16} \mathrm{O}_{4}$ on the basis of the $[\mathrm{M}-\mathrm{H}]^{+}$signal at $\mathrm{m} / \mathrm{z} 211.1$ (calculated 212.1) in the ESIMS. Results of the ${ }^{1} \mathrm{H}-\mathrm{NMR}\left(300 \mathrm{MHz}, \mathrm{MeOH}-d_{4}\right)$ spectroscopic analyses are confirmed by a previous report (Stewart et al., 2005).

\section{Discussion}

Fungi, which are well known for producing many novel chemicals that are directly used as drugs or function as lead structures for synthetic modifications, are among the most important groups of eukaryotic organisms that are being explored for generation of novel therapeutic molecules (Yadav et al., 2018). The marine-derived fungi, especially the Penicillium spp., are rich sources of chemically diverse natural products with a broad range of biological activities. Different halophilic and halotolerant species of the genera Penicillium have been reported from saline habitats such as saline soils, hypersaline regions, saline lakes, etc (Butinar et al., 2011; Yadav et al., 2018).

The compounds isolated from $P$. ochrochloron in this study are well-known compounds, and except for compounds 1 and 8 , they have all been previously reported from Penicillium species.

Talumarin A (1), a dihydroisocoumarin derivative, was first identified from a marine-derived fungus Talaromyces rugulosus associated with the Mediterranean sponge Axinella cannabina (Küppers et al., 2017). Since our study records the second isolation of talumarin A, as well as its first isolation from Penicillium spp., the compound was selected for cytotoxicity and antimicrobial assays. However, talumarin A was not cytotoxic to THP-1 cells and exhibited no antimicrobial activity against the test microorganisms.

Another dihydroisocoumarin derivative, aspergillumarin A (2), has also been reported from several marine-derived fungi including Penicillium sp., Aspergillus sp. and Talaromyces rugulosus (Li et al., 2012; Qi 
et al., 2013; Küppers et al., 2017; Luo et al., 2019). This compound is known to possess antibacterial properties (Li et al., 2012; Qi et al., 2013; Yadav et al., 2014).

Andrastin A (3) has been reported from several Penicillium species including P. roqueforti, P. paneum, P. carneum and P. albocoremium (Uchida et al., 1996; Nielsen et al., 2005; Overy et al., 2005; O'Brien et al., 2006; Rojas-Aedo et al., 2018). Andrastins are meroterpenoids known for inhibiting protein farnesyltransferase (Matsuda and Abe, 2016).

Clavatol (4) a polyketide metabolite produced has been reported from P. griseoroseum, an endophyte of Coffea arabica (da Silva and Rodrigues-Fo, 2010; da Silva et al., 2013). This compound is known to inhibit many plant pathogens (Zhang et al., 2008; da Silva et al., 2013).

3-Acetylphenol (5), also known as 3-hydroxyacetophenone, has been reported from a Penicillium species (Reio, 1959). Methyl 2,5-dihydro-4-hydroxy-5-oxo-3-phenyl-2-furanpropanoate (6) was first reported from an endophytic fungus Chaetomium sp. co-cultured with non-viable (autoclaved) cells of $P$. aeruginosa (Ancheeva et al., 2017).

The anthraquinone, emodin (7) is a well-known plant compound, as well as a mycotoxin produced by certain species of Penicillium and Aspergillus (Frisvad, 1989; Nagashima et al., 2002; Ismaiel et al., 2016). This compound has been reported from $P$. oxalicum, $P$. brunneum, $P$. isiandicum, and $P$. tardum including strains from marine environments (Frisvad, 1989; Wang et al., 2014; Ngan et al., 2017). Emodin is reported to have several diverse biological properties including purgative, anti-inflammatory, antioxidant, antiparasitic, anticancer, and antimicrobial (Chang et al., 1996; Lu et al., 2008; Ismaiel et al., 2016). The chlorinated anthraquinone, 2-chloroemodin (8) is a known metabolite of lichens (Nakano et al., 1972; Cohen et al., 1996; Caro et al., 2012), and which has also been reported from Aspergillus fumigatus (Frisvad et al., 2009). Our study is the first report of 2-chloroemodin from the genus Penicillium.

(-)-Striatisporolide A (9), a butenolide derivative has been previously isolated from Penicillium striatisporum and P. janthinellum (Stewart et al., 2005; Liu et al., 2016). Striatisporolide A is reported to possess antimicrobial properties (Deska and Bäckvall, 2009; Sheng et al., 2019).

Fungi from hitherto less investigated ecological niches like arctic glaciers, deep-sea hydrothermal vents or hypersaline lakes have been attracting considerable attention in recent years as new promising sources for biologically active compounds. This study reveals the potentials of marine environments as host to fungi that express important biological active compounds. These marine fungi hold key of possibilities to the discovery of novel molecules for pharmaceutical, agricultural and applications. With the promising potentials of fungi in the area of novel drug discovery, and in the hope of achieving an effective natural products discovery process through systematic application of co-cultivation (mixed fermentation) of unrelated microbes, and as previously shown (Moussa et al., 2019; Abdel-Wahab et al., 2019), this study confirms co-cultivation as an interesting strategy for the discovery of new natural products.

\section{Conclusions}

This study described the isolation of eight compounds (talumarin A, aspergillumarin A, andrastin A, clavatol, 3-acetylphenol, methyl 2,5-dihydro-4-hydroxy-5-oxo-3-phenyl-2-furanpropanoate, emodin and 2chloroemodin) from the fermentation extract of a marine-derived fungus Penicillium ochrochloron. Also, (-)striatisporolide $\mathrm{A}$, a known butenolide metabolite, was produced by the fungus after co-cultivation with $B$. subtilis. The findings of this study highlight the potential of marine fungi in the discovery of biomolecules with pharmaceutical, agricultural, and industrial applications, as well as the prospects of co-cultivation as an interesting approach for the discovery of new natural products. 


\section{Authors' Contributions}

Funding acquisition: P.M.E.; investigation, methodology, data curation and analysis: P.M.E., Y.G., Y.L. and Lv.G.; writing - original draft: P.M.E.; writing - review and editing, visualization and validation: P.M.E., C.P.E., C.O.E., and F.B.C.O; conceptualization, supervision and research resources: P.P. and R.K. All authors read and approved the final manuscript.

\section{Acknowledgements}

This work was supported by the Africa Research Excellence Fund (AREF) within the frame of the EDCTP-AREF Joint Preparatory Fellowships (grant reference: MRF-157-0034-F-EZE(A) /C0763).

\section{Conflict of Interests}

The authors declare that there are no conflicts of interest related to this article.

\section{References}

Abdel-Wahab NM, Scharf S, Özkaya FC, Kurtán T, Mándi A, Fouad MA, ... Proksch P (2019). Induction of secondary metabolites from the marine-derived fungus Aspergillus versicolor through co-cultivation with Bacillus subtilis. Planta Medica 85(06):503-512. https://doi.org/10.1055/a-0835-2332

Ancheeva E, Küppers L, Akone SH, Ebrahim W, Liu Z, Mándi A, ... Proksch P (2017). Expanding the metabolic profile of the fungus Chaetomium sp. through co-culture with autoclaved Pseudomonas aeruginosa. European Journal of Organic Chemistry 2017(22):3256-3264. https://doi.org/10.1002/ejoc.201700288

Butinar L, Frisvad JC, Gunde-Cimerman N (2011). Hypersaline waters - a potential source of foodborne toxigenic aspergilli and penicillia. FEMS Microbiology Ecology 77(1):186-199. https://doi.org/10.1111/j.15746941.2011.01108.x

Caro Y, Anamale L, Fouillaud M, Laurent P, Petit T, Dufosse L (2012). Natural hydroxyanthraquinoid pigments as potent food grade colorants: an overview. Natural Products and Bioprospecting 2(5):174-193. https://doi.org/10.1007/s13659-012-0086-0

Chang CH, Lin CC, Yang JJ, Namba T, Hattori M (1996). Anti-inflammatory effects of emodin from Ventilago leiocarpa. The American Journal of Chinese Medicine 24:139-142. https://doi.org/10.1142/S0192415X96000189

CLSI (2012). Methods for Dilution antimicrobial susceptibility tests for bacteria that grow aerobically. Clinical and Laboratory Standards Institute ( $9^{\text {th }}$ ed), USA.

Cohen PA, Hudson JB, Towers GHN (1996). Antiviral activities of anthraquinones, bianthrones and hypericin derivatives from lichens. Experientia 52:180-183. https://doi.org/10.1007/BF01923366

da Silva BF, Rodrigues-Fo E (2010). Production of a benzylated flavonoid from 5,7,3',4',5'-pentamethoxyflavanone by Penicillium griseoroseum. Journal of Molecular Catalysis B: Enzymatic 67:184-188. https://doi.org/10.1016/j.molcatb.2010.07.022

da Silva JV, Fill TP, da Silva BF, Rodrigues-Fo E (2013). Diclavatol and tetronic acids from Penicillium griseoroseum. Natural Product Research 27(1):9-16. https://doi.org/10.1080/14786419.2011.647021

Daletos G, Kalscheuer R, Koliwer-Brandl H, Hartmann R, de Voogd NJ, Wray V, Lin W, Proksch P (2015). Callyaerins from the marine sponge Callyspongia aerizusa: cyclic peptides with antitubercular activity. Journal of Natural Products 78(8):1910-1925. https://doi.org/10.1021/acs.jnatprod.5b00266

Deska J, Bäckvall J (2009). Enzymatic kinetic resolution of primary allenic alcohols. Application to the total synthesis and stereochemical assignment of striatisporolide A. Organic \& Biomolecular Chemistry 7:3379-3381. https://doi.org/10.1039/B912128P 
Eze PM, Abonyi DO, Abba CC, Proksch P, Okoye FBC, Esimone CO (2019). Toxic, but beneficial compounds from endophytic fungi of Carica papaya. The EuroBiotech Journal 3(2):105-111. https://doi.org/10.2478/ebtj2019-0012

Frisvad JC, Rank C, Nielsen KF, Larsen TO (2009). Metabolomics of Aspergillus fumigatus. Medical Mycology 47(1):S53-71. https://doi.org/10.1080/13693780802307720

Frisvad JC (1989). The connection between the Penicillia and Aspergilli and mycotoxins with special emphasis on misidentified isolates. Archives of Environmental Contamination and Toxicology 18:452-467 https://doi.org/10.1007/BF01062373

Gomes DNF, Cavalcanti MAQ, Fernandes MJS, Lima DMM, Passavante JZO (2008). Filamentous fungi isolated from sand and water of "Bairro Novo" and "Casa Caiada" beaches, Olinda, Pernambuco, Brazil. Brazilian Journal of Biology 68(3):577-582. https://dx.doi.org/10.1590/S1519-69842008000300016

Imhoff JF, Labes A, Wiese J (2011). Biomining the microbial treasures of the ocean: New natural products. Biotechnology Advances 29:468-482. https://doi.org/10.1016/j.biotechadv.2011.03.001

Imhoff JF (2016). Natural products from marine fungi--still an underrepresented resource. Marine Drugs 14(1):19. https://doi.org/10.3390/md14010019

Ismaiel AA, Rabie GH, Abd El-Aal MA (2016). Antimicrobial and morphogenic effects of emodin produced by Aspergillus awamori WAIR120. Biologia 71:464-474. https://doi.org/10.1515/biolog-2016-0067

Jones EBG (2000). Marine fungi: some factors influencing biodiversity. Fungal Diversity 4:53-73

Kjer J, Debbab A, Aly AH, Proksch P (2010). Methods for isolation of marine-derived endophytic fungi and their bioactive secondary products. Nature Protocols 5:479-490. https://doi.org/10.1038/nprot.2009.233

Küppers L, Ebrahim W, El-Neketi M, Özkaya FC, Mándi A, Kurtán T, ... Proksch P (2017). Lactones from the SpongeDerived Fungus Talaromyces rugulosus. Marine Drugs 15(11):359. https://doi.org/10.3390/md15110359

Li S, Wei M, Chen G, Lin Y (2012). Two new dihydroisocoumarins from the endophytic fungus Aspergillus sp. collected from the South China Sea. Chemistry of Natural Compounds 48:371-373. https://doi.org/10.1007/s10600$012-0254-9$

Liu DS, Huang YL, Ma LY, Lu CJ, Liu WZ (2016). Chemical constituents and their cytotoxic activities of the secondary metabolites of Penicillium janthinellum. Chinese Traditional Patent Medicine 38:830-834.

Liu Y, Kurtán T, Yun WC, Han LW, Orfali R, Müller WE, Daletos G, Proksch P (2016). Cladosporinone, a new viriditoxin derivative from the hypersaline lake derived fungus Cladosporium cladosporioides. The Journal of Antibiotics 69(9):702-706. https://doi.org/10.1038/ja.2016.11

Lu YY, Zhang JL, Qian JM (2008). The effect of emodin on VEGF receptors in human colon cancer cells. Cancer Biotherapy \& Radiopharmaceuticals 23(2):222-228. https://doi.org/10.1089/cbr.2007.0425

Luo XW, Gao CH, Han FH, Chen XQ, Lin XP, Zhou XF, Wang JJ, Liu YH (2019). A new naphthopyranone from the sponge-associated fungus Penicillium sp. XWS02F62. Magnetic Resonance in Chemistry 57(11):982-986. https://doi.org/10.1002/mrc.4930

Ma Y, Galinski EA, Grant WD, Oren A, Ventosa A (2010). Halophiles 2010: life in saline environments. Applied and Environmental Microbiology 76:6971-6981. https://doi.org/10.1128/AEM.01868-10

Matsuda Y, Abe I (2016). Biosynthesis of fungal meroterpenoids. Natural Product Reports 33(1):26-53. https://doi.org/10.1039/c5np00090d

Meier D, Hernández MV, van Geelen L, Muharini R, Proksch P, Bandow JE, Kalscheuer R (2019). The plant-derived chalcone Xanthoangelol targets the membrane of Gram-positive bacteria. Bioorganic \& Medicinal Chemistry 27(23):115151. https://doi.org/10.1016/j.bmc.2019.115151

Moussa M, Ebrahim W, Kalscheuer R, Liu Z, Proksch P (2020). Co-culture of the bacterium Pseudomonas aeruginosa with the fungus Fusarium tricinctum induces bacterial antifungal and quorum sensing signaling molecules. Phytochemistry Letters 36:37-41. https://doi.org/10.1016/j.phytol.2020.01.013

Moussa M, Ebrahim W, Bonus M, Gohlke H, Mándi A, Kurtán T, Hartmann R, Kalscheuer R, Lin W, Liu Z, Proksch P (2019). Co-culture of the fungus Fusarium tricinctum with Streptomyces lividans induces production of cryptic naphthoquinone dimmers. RSC Advances 9:1491-1500. https://doi.org/10.1039/C8RA09067J

Nagashima H, Nakamura K, Gota T (2002). Possible anti-atherogenic effects of emodin, an anthraquinone from Chinese herbs and Aspergillus and Penicillium fungi. Mycotoxins 52(1):23-27. https://doi.org/10.2520/myco.52.23

Nakano H, Komiya T, Shibata S (1972). Anthraquinones of the lichens of Xanthoria and Caloplaca and their cultivated mycobionts. Phytochemistry 12:3505-3508. https://doi.org/10.1016/S0031-9422(00)89847-7 
Ngan NTT, Quang TH, Kim KW, Kim HJ, Sohn JH, Kang DG, Lee HS, Kim Y, Oh H (2017). Anti-inflammatory effects of secondary metabolites isolated from the marine-derived fungal strain Penicillium sp. SF-5629. Archives of Pharmacal Research 40:328-337. https://doi.org/10.1007/s12272-017-0890-5

Nielsen KF, Dalsgaard PW, Smedsgaard J, Larsen TO (2005). Andrastins A-D, Penicillium roqueforti metabolites consistently produced in blue-mold-ripened cheese. Journal of Agricultural and Food Chemistry 53(8):29082913. https://doi.org/10.1021/jf047983u

O'Brien M, Nielsen KF, O'Kiely P, Forristal PD, Fuller HT, Frisvad JC (2006). Mycotoxins and other secondary metabolites produced in vitro by Penicillium paneum Frisvad and Penicillium roqueforti Thom isolated from baled grass silage in Ireland. Journal of Agricultural and Food Chemistry 54:9268-9276. https://doi.org/10.1021/jf0621018

Overy DP, Larsen TO, Dalsgaard PW, Frydenvang K, Phipps R, Munro MHG, Christophersen C (2005). Andrastin A and barceloneic acid metabolites, protein farnesyl transferase inhibitors from Penicillium albocoremium: chemotaxonomic significance and pathological implications. Mycological Research 109(11):1243-1249. https://doi.org/10.1017/S0953756205003734

Qi J, Shao CL, Li ZY, Gan LS, Fu XM, Bian WT, ... Wang CY (2013). Isocoumarin derivatives and benzofurans from a sponge-derived Penicillium sp. fungus. Journal of Natural Products 76(4):571-579. https://doi.org/10.1021/np3007556

Reio L (1959). A method for the paper-chromatographic separation and identification of phenol derivatives, mould metabolites and related compounds of biochemical interest, using a "reference system". Chromatographic Reviews 1:39-74. https://doi.org/10.1016/0009-5907(59)80005-3

Rojas-Aedo JF, Gil-Durán C, Goity A, Vaca I, Levicán G, Larrondo LF, Chávez R (2018). The developmental regulator Pcz1 affects the production of secondary metabolites in the filamentous fungus Penicillium roqueforti. Microbiological Research 212-213:67-74. https://doi.org/10.1016/j.micres.2018.05.005

Satyanarayana T, Raghukumar C, Shivaji S (2005). Extremophilic microbes: diversity and perspectives. Current Science 89:78-90. https://www.jstor.org/stable/24110434

Sheng J, Liu D, Jing L, Xia G, Zhang W, Jiang J, Tang J (2019). Striatisporolide A, a butenolide metabolite from Athyrium multidentatum (Doll.) Ching, as a potential antibacterial agent. Molecular Medicine Reports 20:198-204. https://doi.org/10.3892/mmr.2019.10244

Stewart M, Capon RJ, Lacey E, Tennant S, Gill JH (2005). Calbistrin E and two other new metabolites from an Australian isolate of Penicillium striatisporum. Journal of Natural Products 68(4):581-584. https://doi.org/10.1021/np049614y

Uchida R, Shiomi K, Inokoshi J, Sunazuka T, Tanaka H, Iwai Y, Takayanagi H, Omura S (1996). Andrastins A-C, new protein farnesyltransferase inhibitors produced by Penicillium sp. FO-3929. II. Structure elucidation and biosynthesis. The Journal of Antibiotics 49(5):418-424. https://doi.org/10.7164/antibiotics.49.418

Wang PL, Li DY, Xie LR, Wu X, Hua HM, Li ZL (2014). Two new compounds from a marine-derived fungus Penicillium oxalicum. Natural Products Research 28:290-293. https://doi.org/10.1080/14786419.2013.856906

Wilson ZE, Brimble MA (2009). Molecules derived from the extremes of life. Natural Products Reports 26:44-71 https://doi.org/10.1039/DONP00021C

Yadav AN, Verma P, Kumar V, Sangwan P, Mishra S, Panjiar N, Gupta VK, Saxena AK (2018). Biodiversity of the Genus Penicillium in Different Habitats. In: Gupta VK, Rodriguez-Couto S (Eds). New and Future Developments in Microbial Biotechnology and Bioengineering: Penicillium System Properties and Applications. Elsevier pp 3-18. https://doi.org/10.1016/B978-0-444-63501-3.00001-6

Yadav JS, Mishra AK, Dachavaram SS, Kumar SG, Das S (2014). First enantioselective total synthesis of penicimarin B, aspergillumarins A and B. Tetrahedron Letters 55(18):2921-2923 https://doi.org/10.1016/j.tetlet.2014.03.067

Zhang CL, Zheng BQ, Lao JP, Mao LJ, Chen SY, Kubicek CP, Lin FC (2008). Clavatol and patulin formation as the antagonistic principle of Aspergillus clavatonanicus, an endophytic fungus of Taxus mairei. Applied Microbiology and Biotechnology 78:833-840. https://doi.org/10.1007/s00253-008-1371-z 
OPEN ACCESS

(c) (1)

The journal offers free, immediate, and unrestricted access to peer-reviewed research and scholarly work. Users are allowed to read, download, copy, distribute, print, search, or link to the full texts of the articles, or use them for any other lawful purpose, without asking prior permission from the publisher or the author.

License - Articles published in Notulae Scientia Biologicae are Open-Access, distributed under the terms and conditions of the Creative Commons Attribution (CC BY 4.0) License.

(C) Articles by the authors; SHST, Cluj-Napoca, Romania. The journal allows the author(s) to hold the copyright/to retain publishing rights without restriction. 